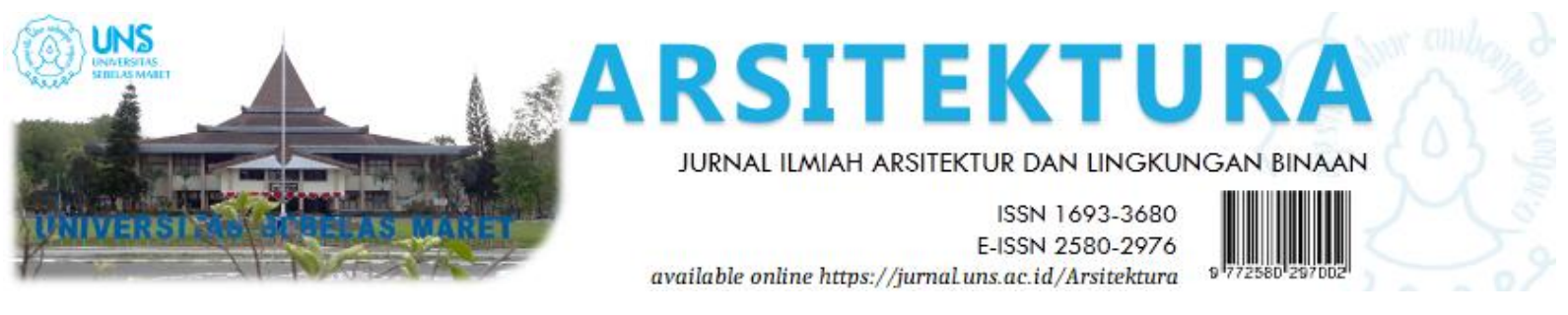

Volume 18 Issue 2 October 2020, pages:291-302

\title{
Implementasi Konsep Arsitektur High-Tech pada Desain Fitness and Wellness Center di Pekanbaru
}

\section{Implementation of High-Tech Architecture Concept in The Design of Fitness and Wellness Center in Pekanbaru}

\author{
Rabudin Rizki $^{1 *}$, Gun Faisal ${ }^{2}$, Yohannes Firzal ${ }^{3}$ \\ Program Studi Arsitektur, Fakultas Teknik Universitas Riau ${ }^{1 *}$ \\ Rabudin.rizki3458@student.unri.ac.id \\ Program Studi Arsitektur, Fa kultas Teknik Universitas Riau ${ }^{2}$ \\ Program Studi Arsitektur, Fa kultas Teknik Universitas Riau ${ }^{3}$
}

DOI: https://doi.org/10.20961/arst.v18i2.42871

Received: July 12, 2020 Revised: October 13,2020 Accepted: October 17, 2020 Available online: October 31, 2020

\begin{abstract}
Pekanbaru is a developing capital city that can be seen from the density of community activities in their daily lives. This requires having a fit and healthy body. A fit and healthy lifestyle is also an importantrequirementfor the body. Fitness and good body beauty is the dream of every human being. Lack of fitness in the body will makeyou weak and less enthusiastic in carrying outyour daily routine. From this problem, we need a place that accommodates fitness activities and physical and spiritual health of the body. Generally, Fitness and Wellness facilities in Pekanbaru are still located in shophouses, residences, shopping centers and part of the supporting facilities for star-rated hotels. Therefore a Fitness and Wellness Center is needed that expresses fitness and health by supporting various physical and physical and spiritual activities that have never existed before by presenting aesthetics, technology and building a supporting structure. For that, we need a high-tech architectural principles approach that exposes a structure that is not only load-bearing but also aesthetically pleasing to this building.
\end{abstract}

Keywords: Fitness, Wellness, Architecture High-Tech

\section{PENDAHULUAN}

Kota Pekanbaru mengalami perkembangan yang meningkat, hal ini dapat dilihat dari berbagai aktifitas sehari-hari masyarakat. Padatnya aktifitas masyarakat membutuhkan tubuh yang bugar dan sehat. Gaya hidup yang sehat merupakan salah satu kebutuhan yang penting bagi tubuh. Untuk mendapatkan tubuh yang bugar dan sehat tentunya dengan berolahraga, merawat serta menjaga kesehatan. Semakin berkembangnya zaman, penggunaan teknologi dalam pekerjaan mengakibatkan kurangnya aktifitas fisik pada masyarakat. Bekerja yang berlebihan menyebabkan rasa lelah pada fisik, jiwa dan pikiran. Pola hidup yang tidak sehat akan menyebabkan terganggunya metabolisme tubuh. Olahraga merupakan aktifitas melatih tubuh, baik jasmani maupun rohani. Tidak hanya persoalan kesehatan, tetapi keindahan bentuk tubuh menjadi suatu perhatian pada masyarakat. Kepercayaan diri akan meningkat apabila memiliki penampilan fisik yang bagus. Banyaknya kalangan masyarakat perkotaan 
yang mengalami kelebihan berat badan/obesitas dan kurangnya kebugaran pada tubuh akan membuat lemas dan kurang bersemangat dalam rutinitas sehari-hari. Mempertahankan tingkat kesehatan yang baik sangat penting dalam kehidupan guna meminimalisir stress, mengurangi resiko penyakit dan memiliki sosial yang positif untuk kehidupan yang sehat (Gesyari, 2018). Aktifitas pada wellness lebih mengedepankan kesehatan fisik, jiwa dan pikiran, berbeda dengan fitness lebih kepada kebugaran tubuh tetapi memiliki tujuan yang sama yakni untuk memperoleh kesehatan dan kebugaran jasmani dan rohani. Pada umumnya fasilitas fitness berada di ruko-ruko, rumah tinggal, pusat perbelanjaan dan bagian dari fasilitas pendukung hotel-hotel berbintang (Pratama, 2018). Tempat fitness dan wellness yang berada di Pekanbaru masih menggunakan ruko-ruko, rumah tinggal dan hotel-hotel sebagai tempat kegiatan fitness yang masih terbilang fasilitasnya pun juga terbatas. Dengan adanya Fitness and Wellness Center menjadi pusat dari tempat berlangsungnya kegiatan kebugaran dan kesehatan diharapkan tempat dan fasilitasnya lebih memadai dari yang lainnya.

\subsection{Kajian Teori Fitness}

Fitness merupakan tempat berolahraga didalam ruangan dengan berbagai macam latihan pengolahan tubuh dengan menyediakan fasilitas dan peralatan teknologi untuk memperoleh kegiatan kebugaran dan kesehatan (Syahira, 2019). Fitness Center merupakan gabungan dari 2 kata dalam bahasa inggris yaitu fitness (kebugaran) dan center (pusat) yang artinya pusat kebugaran (Akbar, 2008). Giriwijoyo (2007) mengatakan bahwa pusat kebugaran adalah suatu kegiatan dalam ruangan dengan menawarkan kegiatan olahraga dengan menggunakan alat, atau tanpa menggunakan alat-alat yang mahal dan canggih, yang di antaranya bertujuan kesehatan atau prestasi. Fitness Center menjadi salah satu bidang usaha yang diminati oleh banyak masyarakat. Hal ini dapat dilihat dari banyaknya wadah Fitness Center di Indonesia. Selain bertujuan sebagai tempat berolahraga, tetapi juga untuk meningkatkan keuntungan finansial bagi pemiliknya.

\subsection{Kajian Teori Wellness}

Menurut Myers dkk (2000) dalam Nursamsiah, Endang, dan Karsih (2015) mengatakan wellness diartikan sebagai cara hidup yang berorientasi pada kesehatan dan well-being yang optimal antara tubuh, pikiran dan semangat yang menyatu pada individu untuk mendapatkan hidup yang lebih baik dalam komunitas manusia dan alam. Sedangkan menurut Saputra (2019) Wellness Centeradalah sebuah pusat kebugaran baik jasmani maupun rohani, yang lebih spesifiknya adalah tempat dimana para professional kesehatan mental dan medis, ahli gizi, dan trainer kebugaran menyediakan tempat layanan dan perawatan untuk kesehatan tubuh dan pikiran.

Myers dkk (2000) dalam Kusuma, Aji Bayu dan Tri P.W. (2017) ada 6 komponen dalam wellness, yaitu:

a. Spiritual Wellness

Spiritual wellness merupakan sebuah nilai kepercayaan atau panduan untuk hidup. Setiap orang punya persepsi mengenai sprtitual. Dalam melakukan suatu aktifitas maka disandarkan nilai atau prinsip spiritual seperti kejujuran dan membersihkan pikiran dari hal negative.

b. Sosial Wellness

Sosial wellness adalah kemampuan untuk menjaga dan mengembangkan hubungan dengan orang lain, respek dan sikap toleransi terhadap perbedaan pendapat dan kepercayaan. Dalam beraktifitas saling menguatkan dan mendukung dalam mencapai suatu tujuan.

\section{c. Physical Wellness}

Physical wellness meliputi kemampuan untuk mengerjakan kegiatan sehari-hari, meningkatkan tenaga dalam tubuh, serta kecerdasan otot, mempertahankan nutrisi dengan makanan sehat dan lemak sehat dalam tubuh, dan mengurangi penyalahgunaan alkohol dan obat-obatan atau penggunaan produk tembakau. Physical wellness meningkatkan skill, memperhatikan penampilan serta membangun kepercayaan diri dengan latihan fisik. 
d. Emosional Wellness

Emotional wellness adalah kemampuan untuk mengontrol dan mengekspresikan emosi secara tepat dan menghargai diri sendiri. Setiap mencapai tujuan ada yang mengalami kejayaan dan kekalahan tetrapi bisa diperbaiki dan ditingkatkan sesuai dengan kemampuan.

e. Intelektual Wellness

Intelektual wellness adalah mempelajari dan menggunakan informasi secara efektif untuk pribadi, keluarga, dan perkembangan karir. Intelektual wellness berarti suatu usaha untuk pertumbuhan yang berkelanjutan dan pembelajaran mengatasi tantangan secara efektif. Intelekrual wellness dalam aktifitasnya mampu meningkatkan kemampuan, pengetahuan dan teknologi dan saling berbagi pengetahuan kepada sesama.

f. Occupational Wellness

Occupational Wellness adalah kemampuan untuk menyeimbangkan pekerjaan dan waktu luang. Sikap terhadap kerja, sekolah, karir, dan tujuan karir, kesan yang positif dari pekerjaan dan prestasi sekolah dan hubungan dengan orang lain. Setiap orang mampu meningkatkan pengetahuan dan informasi sebuah kemampuan dan skill suatu tujuan yang bisa menjadi sebuah pekerjaan.

\subsection{Kajian Teori Arsitektur High-Tech}

Arsitektur high-tech merupakan gaya arsitektur yang muncul pada tahun 1970 dengan penerapan kecanggihan teknologi serta penggunaan elemen-elemen struktural yang dominan dengan material pabrikasi pada elemen eksterior, interior serta utlitas bangunan. Tujuan arsitektur high-tech adalah menampilkan unsur teknik bangunan yang kemudian di ekspose. Arsitektur high-tech mengarahkan untuk mencapai suatu industri estetika yang baru yang dipicu oleh pembaharuan paham dalam perkembangan teknologi, namun tetap mempertahankan elemen-elemen fungsional dari arsitektur modern (Telew and Steven, 2011).
Dalam bukunya High-Tech Architecture (1988), Collin Davies menyatakan High Tech Architecture merupakan sebuah langgam yang terinspirasi dari perkembangan industri dengan tipologi bangunan yang menyerupai bangunan industri. High Tech dalam arsitektur berbeda dengan High-Tech dalam industri yang berarti elektronik, komputer, chip, robot, sedangkan dalam arsitektur, High -Tech merupakan sebuah gaya dari bangunan. Karakteristik high-tech dalam arsitektur lebih kepada pengguanaan bahan material seperti kaca,metal dan plastik (Endirastomo, 2009).

Fitness and Wellness Center merupakan penggabungan 2 fungsi sebagai pusat sarana olahraga kebugaran dan kesehatan jasmani dan rohani. Fitness yang merupakan olahraga kebugaran menampilkan ekspresi kebugaran dan kekuatan pada tubuh sedangkan wellness yang merupakan pemeliharaan kesehatan jasmani dan rohani dengan keindahan fisik melalui berbagai cara latihan. Kesan yang terbuka menjadikan perancangan Fitness and Wellness Center sebagai daya tarik pengunjung yang bisa melihat kegiatan dari luar dengan fleksibilitas ruangan olahraga. Penerapan Pendekatan arsitektur high-tech dapat menjadi tema pada perancangan Fitness and Wellness Center yang menampilkan ekspresi dari kekuatan dan keindahan pada tubuh sehingga sesuai dengan prinsip arsitektur high-tech yang mengekspos struktur yang tidak hanya sebagai kekuatan tetapi juga sebagai estetika, kesan yang terbuka (inside-out), fleksibilitas ruang dengan berbagai wahana latihan serta penggunaan material yang fungsional dan estetis.

\subsection{Preseden Fitness Center}

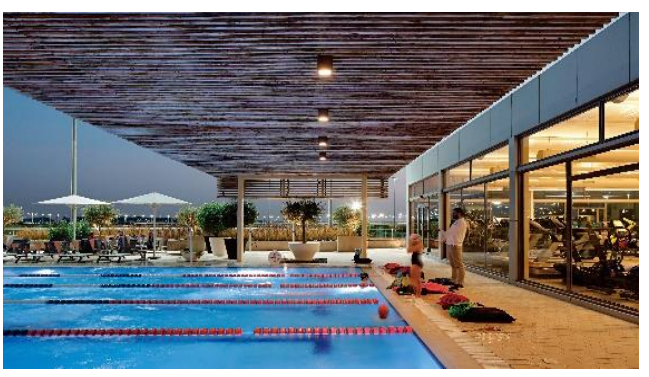

Gambar 1. Inspire Pure Fitness 
Bangunan ini terletak di Kuwait City, Kuwait dengan Total area sekitar $1300 \mathrm{~m} 2$. Pemilik berniat untuk mengembangkan ruang olahraga baru termasuk ruang kebugaran kelompok, kotak Crossfit, area layanan makanan, sauna, loker dan ruang ganti dengan pancuran dan toilet, ruang Administrasi dan Fisioterapi.

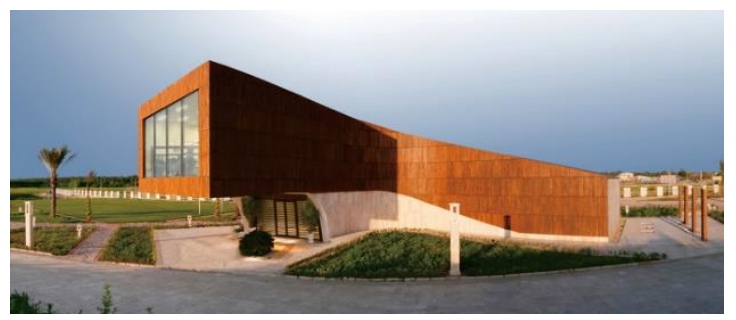

Gambar 2. DashteNoor's Gym

Bangunan Dashte Noor's ini berlokasi di Mazandaran, Iran yang merupakan karya desain dari arsitek Narges Nassiri. Luas bangunan ini 405 m2 yang dibangun pada tahun 2013. Bangunan ini adalah salah satu bangunan publik yang menyediakan fasilitas kebugaran tubuh. Konsep ini merancang bangunan dengan massa dinamis yang merupakan bagian integral dan bagian dari lanskap di sekitarnya.

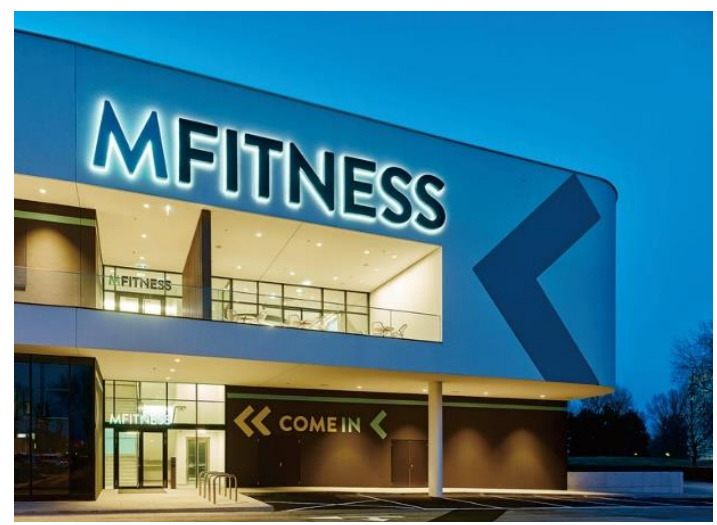

Gambar 3. MFitness

Bangunan MFitness ini didirikan pada tahun 2015 berlokasi di Wiene Neustatd, Austria oleh Smertnik Kraut. Luas bangunan MFitness ini $2430 \mathrm{~m} 2$ dengan fungsi Fitness Center. Bangunan ini memiliki pintu masuk utama ke jalan, koneksi ke mal, yang letaknya bersebelahan dan koneksi ke garasi parkir. Platform konstruksi baja menawarkan ruang pribadi kepada pengguna sebagai tempat latihan, berbeda dengan lantai utama, tempat pelatihan umum memang dipromosikan. Dengan konsep ruang yang luas, yang mencakup area untuk komunikasi, kesehatan, tempat duduk, teras, fitness menawarkan ruang penggunanya untuk berkomunikasi dan privasi. Di sisi aula pelatihan ada kamar yang ditetapkan untuk pelatihan khusus, seperti pemintalan, ruang senam yang lebih besar dan lebih kecil, ruang istirahat dan ruang plat daya.

\subsection{Preseden Arsitektur High-Tech}

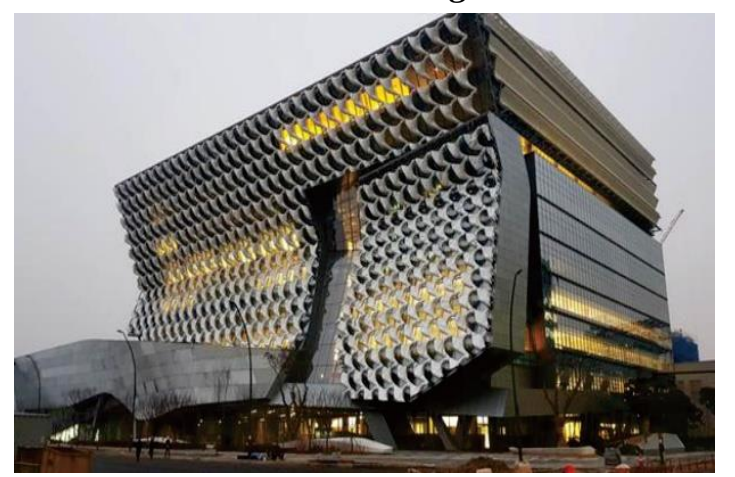

Gambar 4. The Kolon One \& Only Tower

Bangunan The Kolon One \& Only Tower ini di desain oleh Morpholis yang merupakan salah satu studio arsitek yang berasal dari Los Angeles. Berlokasi di Seoul, Korea Selatan berfungsi sebagai exhibition, kantor dan komersil. Struktur yang di ekspos yang meyelimuti bangunan tersebut dan memeperlihatkan ekspresi pada bangunan. Teknologi yang digunakan pada bangunan ini adalah ultra-thin concrete roof dan photovoltaic panels. Penggunaan dinding kaca, baja, dan alumunium pada bangunan. Sehingga memperlihatkan ke luar bangunan dengan penggunaan kaca transparan.

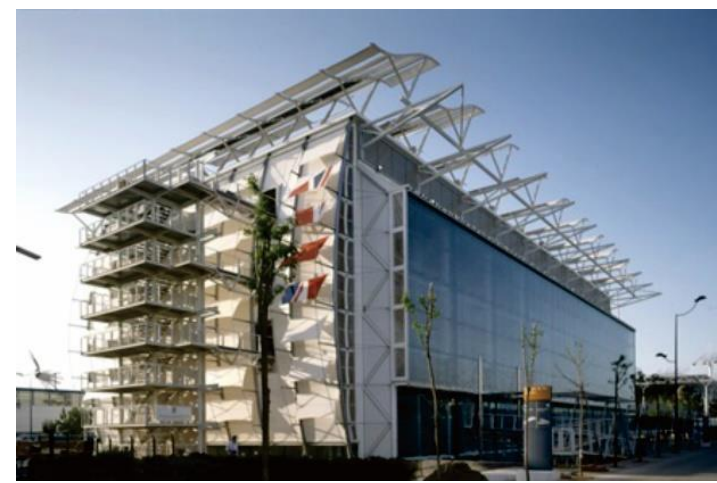

Gambar 5. British Pavilion Expo

Bangunan Pavillion Inggris ini dirancang oleh arsitek Nicholas Grimshaw \& partner pada kompleks Expo 1992 di kota Seville di Spanyol, sebagai perwujudan hasil sayembara tahun 1989 yang dimenangkan oleh arsitek tersebut. 
Bangunan ini dirancang dengan pertimbangan iklim setempat dimana suhu udara musim panas saat dilangsungkan Expo ini dapat mencapai 450C. Beberapa strategi rancangan yan digunakan untuk mengantisipasi kondisi udara ini adalah, pertama, menggunakan tabir air pada dinding timur yang berfungsi sebagai filter radiasi matahari pagi tanpa menghilangkan sama sekali penerangan yang diberikan oleh sinar matahari tersebut disamping sebagai pendingin bangunan.

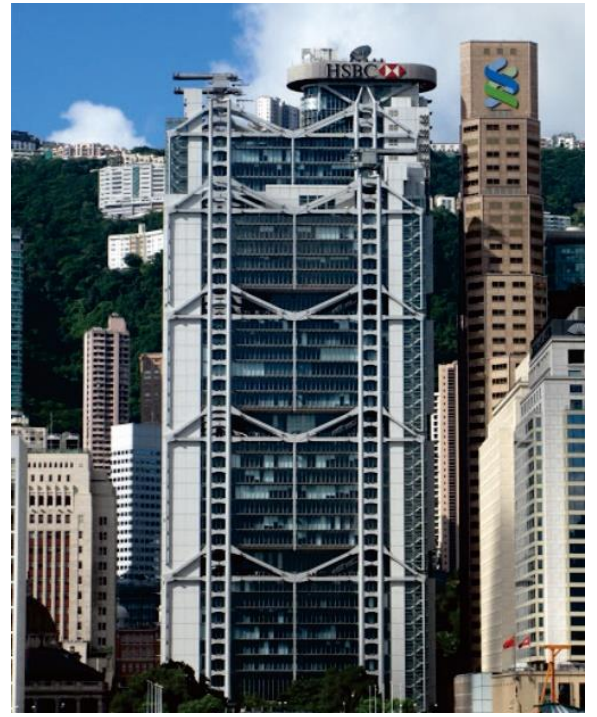

Gambar 6. Hongkong Shanghai Bank

Bangunan ini karya arsitek ternama Norman Foster yang dibangun dari tahun 1979-1986. Norman Foster menonjolkan pengeksposan struktur sebagai daya tarik dari tampilan bangunan serta memasukkan unsur-unsur dari luar bangunan yang mampu menhidupkan bangunan. Dapat dilihat pada bangunan struktur yang dieskpos pada luar bangunan dengan memberi lapisan aluminium abu-abu dan panelpanel silver metalik yang dipadu dengan tangkapan angin berlapis aluminium. Terdapat pencahayaan yang cukup pada atrium dengan ketinggian $52 \mathrm{~m}$ serta kaca pada langit-langit setinggi $12 \mathrm{~m}$. Bagian dalam bangunan diperlihatkan ke luar bangunan. Peninggian bangunan sebanyak $12 \mathrm{~m}$ ini memberikan public space, yang terhubung dengan eskalator menuju hall utama bank guna menciptakan semi public space dengan atrium berlantai 10 , desain gondola juga menghadirkan kesatuan bangunan secara keseluruhan.

\section{METODE}

Dalam perancangan Fitness and Wellness Center di Pekanbaru dengan arsitektur hightech ini metode dalam pengumpulan data dengan 2 metode yaitu data primer yaitu data yang dapat diperoleh langsung melalui survey lapangan terhadap objek kebutuhan, sedangkan metode yang kedua dengan data sekunder yang dapat diperoleh dari studi literatur yaitu pada jurnal, skripsi, thesis, disertasi, buku dan media.

Strategi perancangan pada Fitness and Wellness Center di pekanbaru yang sesuai dengan penerapan tema arsitektur high-tech dimulai dengan pemahaman pada studi literature, survey, analisa fungsi, program ruang, analisa sistem struktur, analisa sistem bangunan, analisa site, perzoningan, analisa penerapan tema, konsep, bentuk massa sehingga mendapatkan hasil desain. Maka dapat disimpulkan ke dalam bagan alur perancangan sebagai berikut:

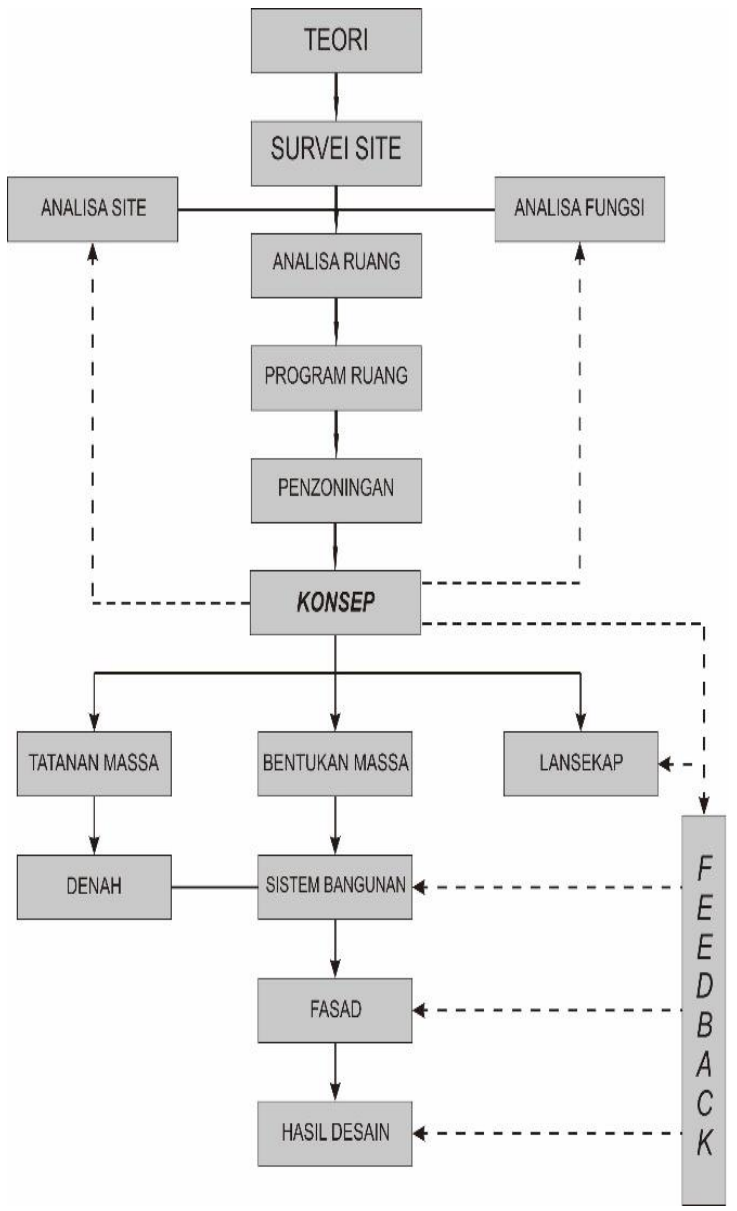

Gambar 7. Bagan Alur Perancangan 


\section{HASIL DAN PEMBAHASAN}

\subsection{Fungsi Perancangan}

Fungsi utama dari bangunan ini adalah fungsi olahraga sebagai pusat kebugaran atau fitness yang memfasilitasi kegiatan-kegiatan olahraga yang melibatkan pada latihan pembentukan dan kebugaran tubuh. Terdapat beberapa jenis kegiatan kebugaran yaitu olahraga fitness yang terbagi menjadi 2 tempat yakni umum dan khusus wanita, kardio, martial art, sauna dan senam aerobik. Pada bangunan ini juga dilengkapi dengan penyediaan auditorium body contest sebagai tempat berlangsungnya event maupun perlombaan sebagai tujuan prestasi. Sedangkan Fungsi sekunder dari bangunan ini adalah fungsi sebagai wellness center yang merupakan kegiatan yang melibatkan aktifitas pemeliharaan kesehatan tubuh, jiwa dan pikiran sesuai dengan 6 komponen pada wellness. Ada Berbagai jenis kegiatan wellness yaitu yoga, klinik yang terbagi menjadi 2 bagian yaitu muscular aesthetic dan beauty clinic, spa, penyediaan kolam renang, perpustakaan dan healthy food bar.

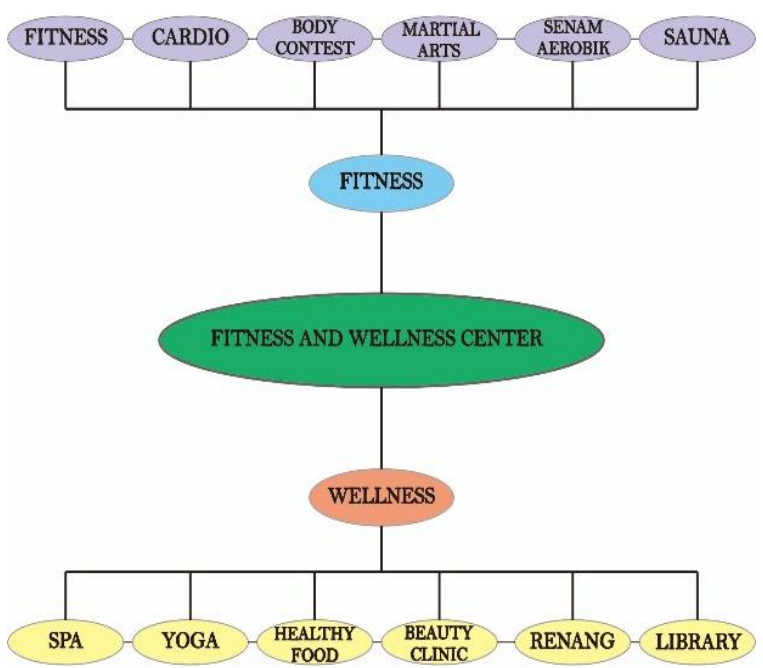

Gambar 8. Ba gan Jenis Kegiatan Fungsi

\subsection{Pelaku Kegiatan}

Berdasarkan analisa kegiatan tedapat beberapa pola kegiatan yang berbeda-beda, sehingga dapat disimpulkan pelaku kegiatan terdiri atas pengunjung, pengelola dan service. Pengunjung dapat melakukan segala jenis kegiatan di area publik yang sesuai dengan kebutuhan kegiatan yang diinginkan. Pengunjung dapat melakukan aktifitas pada fitness area, wellness area serta fasilitas pendukung lainnya seperti penjualan alat olahraga fitness pada retail, musholla dan cafeteria.

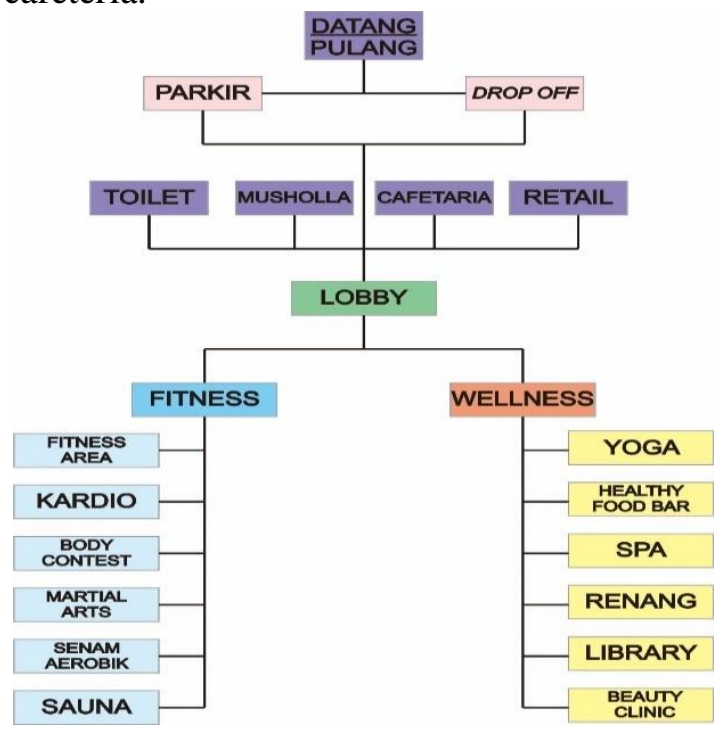

Gambar 9. Mapping Alur Kegiatan Pengunjung

Sedangkan pengelola merupakan pihak yang bertugas mengatur segala bentuk aktifitas pada Fitness and Wellness Center. Kegiatan dari pihak pengelola berupa pengembangan fasilitas sarana dan prasarana bangunan, pengarsipan file, pencatatan segala bentuk aktifitas, pengaturan aset, perhitungan biaya yang dibutuhkan oleh kegiatan-kegiatan yang ada didalam bangunan.

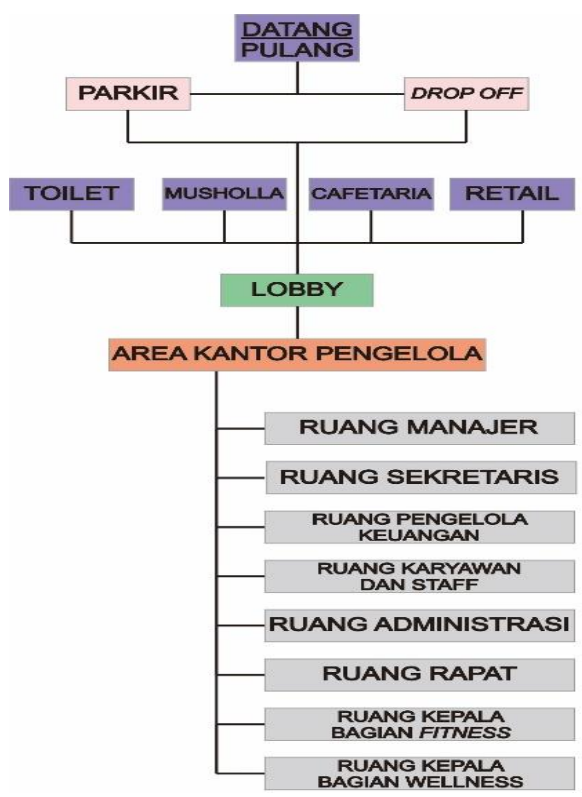

Gambar 10. Mapping Alur Kegia tan Pengelola 
Tenaga service merupakan pihak yang mengatur keamanan, menjaga kebersihan sehingga kenyamanan dalam segala aktifitasnya terjaga pada Fitness and Wellness Center.

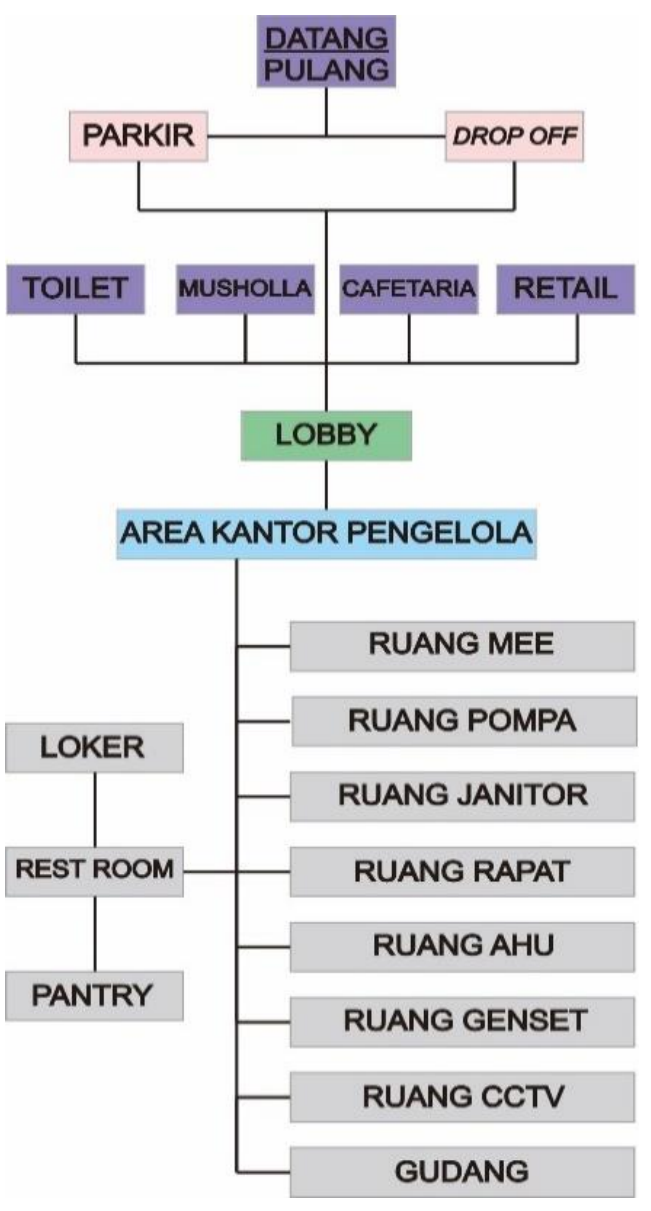

Gambar 11. Mapping Alur Kegiatan Service

\subsection{Kebutuhan Ruang}

Berdasarkan analisis perhitungan program ruang, diketahui kebutuhan ruang pada Fitness and Wellness Center. Maka perhitungan luas, standar, jumlah kebutuhan ruang akan dihitung berdasarkan Neufret Architect Data (NAD) karya Ernest Neufret dan Asumsi (AS). Analisis perhitungan besaran ruang dapat dilihat pada tabel berikut:
Tabel 1. Tabel Total Kebutuhan Ruang

\begin{tabular}{lc}
\hline \multicolumn{1}{c}{ Area } & Total Luas (m2) \\
\hline $\begin{array}{l}\text { Fasilitas Penemrimaan dan } \\
\text { Pelayanan Informasi }\end{array}$ & 400.4 \\
\hline Fasilitas Utama & $3.318,484$ \\
\hline Fasilitas Pengelola & 486,096 \\
\hline Fasilitas Service & 294,3 \\
\hline $\begin{array}{l}\text { Fasilitas Penunjang dan } \\
\text { Pendukung }\end{array}$ & $1.117,74$ \\
\hline $\begin{array}{l}\text { Fasilitas Ruang Luar dan } \\
\text { Parkir }\end{array}$ & $4.882,5$ \\
\hline \multicolumn{1}{c}{ Total } & $10.449,52$ \\
\hline
\end{tabular}

\subsection{Site Perancangan}

Fitness and Wellness Center berlokasi di Jalan Jenderal Sudirman , Kecamatan Bukit Raya, Kelurahan Tangkerang Tengah, Kota Pekanbaru, Provinsi Riau. Dengan luas lahan \pm $11.000 \mathrm{~m}^{2} / 1.1 \mathrm{Ha}$ dengan kontur relatif datar dan kondisi eksisting yang merupakan lahan kosong serta KDB 70\%. Lokasi ini merupakan lokasi yang strategis dengan alasan lokasi berada di Jalan Jenderal Sudirman yang merupakan pusat Kota Pekanbaru yang sering dilalui oleh masyarakat sehingga mudah untuk pencapaian ke lokasi site; lokasi berada di kawasan perdagangan dan jasa yang sesuai dengan fungsi bangunan yang menawarkan perdagangan dan jasa; berada diantara 2 jalan besar yaitu Jalan Harapan Raya dan Jalan Arifin ahmad serta lokasi site berada pada area utilitas kota.

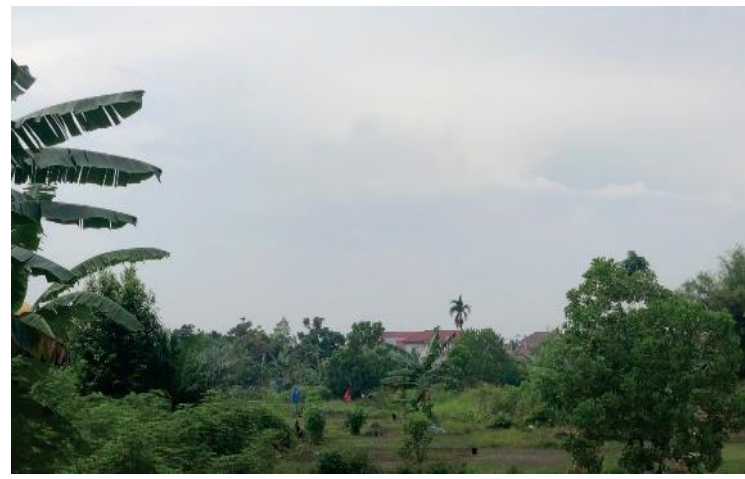

Gambar 12. Lokasi perancangan

Adapun batas-batas lokasi site yaitu:

- Sebelah Utara : Balai Sudirman

- Sebelah Selatan : : Teras Kayu Resto

- Sebelah Barat : Daerah Pemukiman

- Sebelah Timur : : Sudirman Square 
Pergerakan matahari dari Timur ke Barat terdapat pada depan ke belakang bangunan. Letak bangunan menghadap ke arah timur sehingga dapat memanfaatkan cahaya alami yang lebih besar. Penggunaan kaca pada double fasad akan meminimalisir panas dan cahaya matahari yang masuk kebangunan. Untuk pergerakan angin cukup bagus karena di sekeliling bangunan tidak ada bangunan tinggi serta adanya pepohonan yang akan membantu sirkulasi angin yang lebih baik.

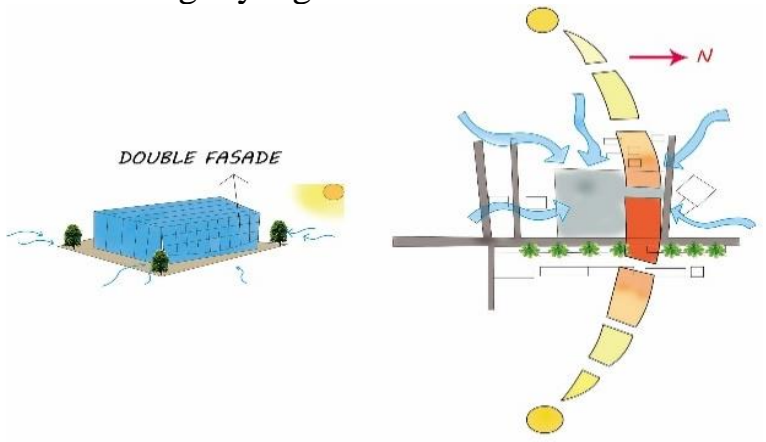

Gambar 13. Arah Matahari dan Pergerakan Angin

Bagian Timur merupakan Jalan Jendral Sudirman sebagai jalan raya dengan 2 jalur, banyak dilalui oleh kendaraan masyarakat sehingga tingkat kebisingan pada lokasi site ini tinggi. Sedangkan pada sisi utara dan selatan terdapat bangunan yang tingkat kebisingan rendah. Pada arah barat site, hanya terdapat beberapa rumah sebagai daerah pemukiman dengan tingkat kebisingan hampir tidak ada.

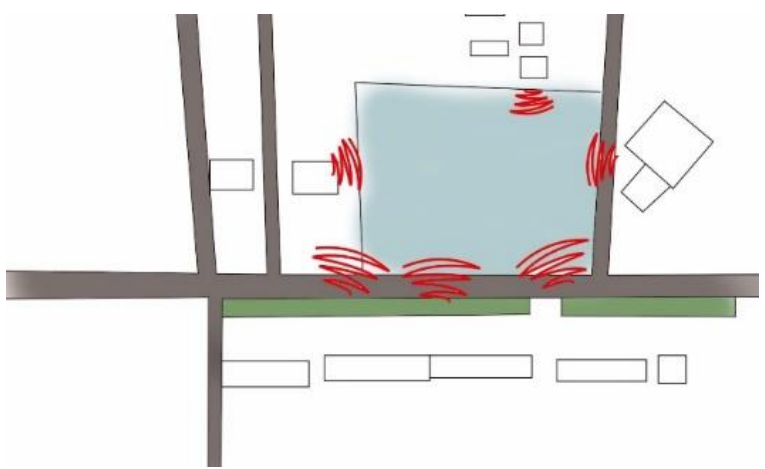

Gambar 14. Kebisingan pada Lokasi Site
Menanggapi tingkat kebisingan yang tinggi pada lokasi site, bangunan diletakkan jauh dari area dengan tingkat kebisingan tinggi yaitu di Jalan Jendral Sudirman. Pemanfaatkan vegetasi sebagai buffer untuk mengurangi tingkat kebisingan pada bangunan.

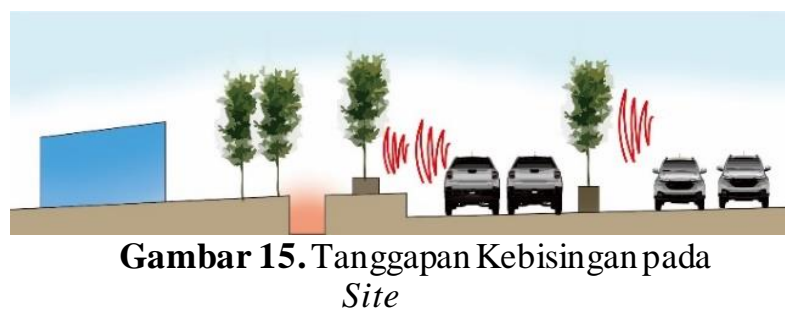

\subsection{Penerapan Tema pada Perancangan}

Penerapan tema perancangan arsitektur hightech pada bangunan Fitness and Wellness Center dengan menerapkan beberapa ciri/karakteristik tema dapat dilihat pada table berikut:

Tabel 2. Ta bel Total Kebutuhan Ruang

\begin{tabular}{ll}
\hline Karakteristik & \multicolumn{1}{c}{ Pengaplikasian } \\
\hline Struktur Yang & $\begin{array}{l}\text { Penerapan struktur yang di } \\
\text { di Ekspose }\end{array}$ \\
& ekspose tidak hanya sebagai \\
& estetika dari bangunan itu \\
& sendiri. \\
\hline Penggunaan & Penggunaan material yang \\
bahan Material & fungsional dan estetis \\
Kaca dan Baja & merupakan karakteristik dari \\
& arsitektur high-tech. Hampir \\
& seluruh bangunan arsitektur \\
& high-tech mengunakan \\
& material kaca dan baja. \\
& Penggunaanbajaterdapatpada \\
frame untuk dinding kaca dan & struktur ruang rangka.
\end{tabular}




\begin{tabular}{ll}
\hline Karakteristik & \multicolumn{1}{c}{ Pengaplikasian } \\
\hline Penerapan & Penggunaan teknologi pada \\
Teknologi dan & bangunan terdapat pada \\
Ekologi & penggunaan panel photovoltaic \\
Bangunan & pada dinding dan a tap kaca \\
& atau skylight. Penerapan ini \\
& guna mendukung fungsi pada \\
& kegiatan dalam ba ngunan. \\
& Sedangkan Penerapan ekologi \\
& pada bangunan dilakukan \\
& dengan mempertimbangkan \\
& iklim dan suhu yang cukup \\
& tinggi di Kota Pekanbanu. \\
& Penggunaan double fasad \\
& dengan material dari kaca pada \\
& bangunan yang menjadi sebuah \\
& solusi agar panas matahari \\
& yang masuk kedalam ruangan \\
dapat dikurangi. Penggunaan \\
material ETFE ((Ethylene \\
Tetrafluoroethylene) yang \\
merupakan material ramah \\
lingkungan dengan transmisi \\
cahaya yang baik dengan \\
kualitas yangbagus serta tidak \\
terpengaruh oleh sinar \\
ultraviolet. \\
\hline Penggunaan warna yang cerah \\
Warna yang & terdapat pada material struktur \\
dan utilitas pada bangunan \\
Ferah & Fitness and Wellness Center \\
& sehingga orang memahami \\
masing-masing dari fungsi & antara struktur dan utilitas. \\
\hline
\end{tabular}

\subsection{Konsep}

Fitness and Wellness Center merupakan pusat latihan kebugaran dan kekuatan pada tubuh dengan pemeliharaan kesehatan jasmani dan rohani dengan keindahan fisik. Sehingga konsep dasar yang akan digunakan pada Fitness and Wellness Center adalah expression of muscle yang mengacu pada pengekpresian dari kebugaran dan kesehatan pada tubuh yang sesuai dengan fungsi rancangan. Penerapan expression of muscle diambil dari 2 sifat gerakan pada otot yang membentuk sebuah ekspresi bentuk yaitu kontraksi dan relaksasi yang merupakan bagian otot yang bekerja pada tubuh untuk mengubah energi kimia menjadi kekuatan untuk bergerak yang disebut otot lurik. Mengekspresikan kekuatan yang menjadikan daya tarik dari penerapan konsep expression of muscle pada bangunan. Hal ini sesuai dengan prinsip dari tema arsitektur high- tech yang mengekspose struktur yang tidak hanya sebagai kekuatan dari menahan beban namun juga sebagai estetika dari bangunan itu sendiri.

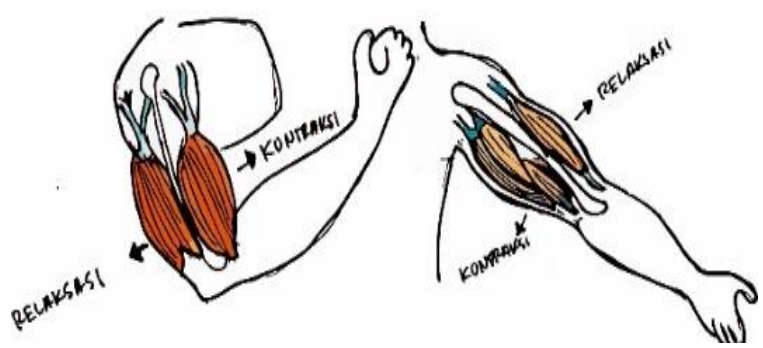

Gambar 16. Gerakan Kontraksi dan Relaksasi padaOtot

\subsection{Transformasi Bentuk}

Transformasi bentuk pada perancangan Fitness and Wellness Center mengambil dari dari 2 pola bentuk sifat gerakan pada otot yaitu kontraksi dan relaksasi yang merupakan gerak tarik menarik pada otot. Pergerakan kontraksi dan relaksasi menghasilkan bentuk lengkungan pada otot yang menjadikan estetika pada bagian tubuh juga diterapkan pada bentukan massa.
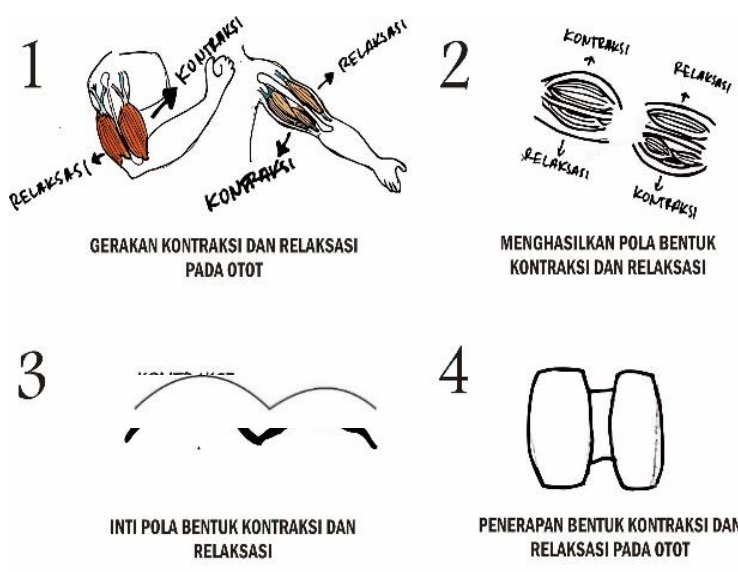

5

4

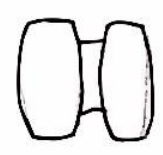

PENERAPAN BENTUK KONTRAKSI DAN RELAKSASI PADA OTOT

6
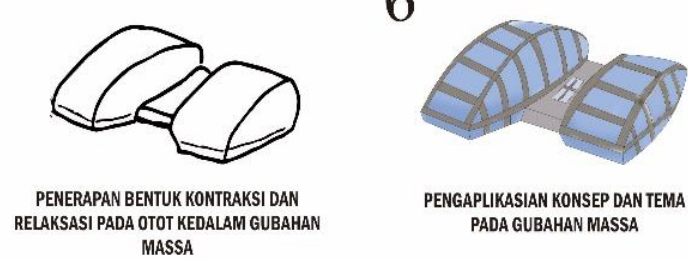

Gambar 19. Transformasi Konsep 


\subsection{Konsep Interior}

Konsep Interior pada perancangan Fitness and Wellness Center bernuansa pada kegiatan kebugaran dan pemeliharaan Kesehatan jasmani dan rohani. Pada ruangan fitness mengedepankan pengeksposan struktur dan penggunaan material kaca dan baja.

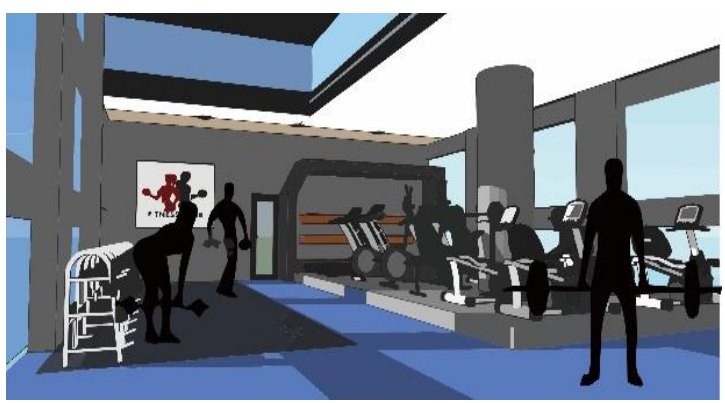

Gambar 17. Konsep Interior Fitness

Sedangkan pada ruangan wellness dominan menggunakan material alam seperti kayu.

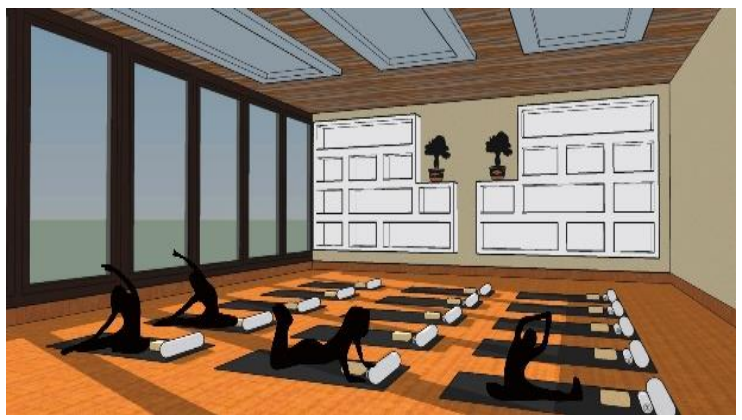

Gambar 18. Konsep Interior Wellness

\subsection{Konsep Rencana Tapak}

Pada rencana tapak pada perancangan Fitness and Wellness Center dirancang menyesuaikan pada penerapan konsep yang terbagi dari 4 zona yang terdiri dari zona bangunan, zona parkir pengelola, zona parkir pengunjung dan zona RTH.

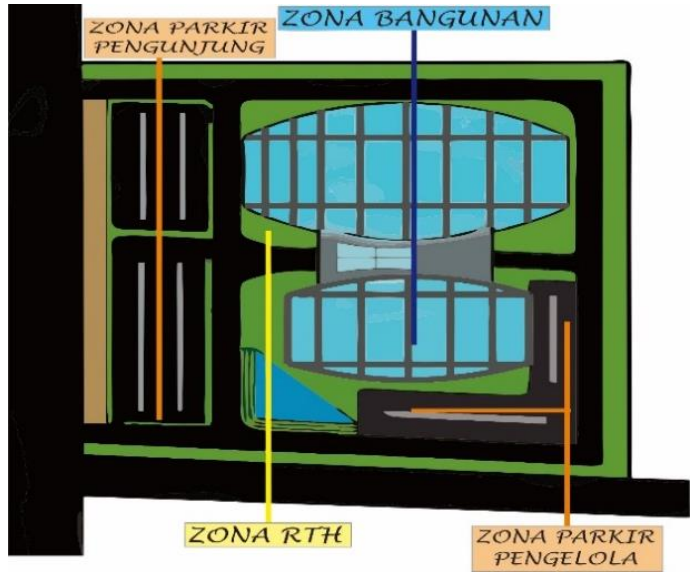

Gambar 20. Konsep Rencana Tapak

\subsection{Konsep Lansekap}

Sirkulasi pada perancangan Fitness and Wellness Center ini terdapat 2 jalur dengan lebar jalan $5 \mathrm{~m}$. Sirkulasi pada Fitness and Wellness Center memiliki 1 akses jalan masuk dari Jalan Jendral Sudirman dan keluar menuju Jalan Jendral Sudirman. Sedangkan sirkulasi untuk pejalan kaki disediakan pedestrian way yang dapat dilalui disekitar bangunan. Sedangkan tempat parkir terbagi 2 titik yaitu parkir pengunjung dan parkir pengelola. Pada penataan parkir kendaraan dengan 2 arah bersebrangan antara parkir mobil dan parkir motor dengan kemiringan 30 derajat. Tempat parkir juga ditanami beberapa pohon sebagai peneduh dan petunjuk arah jalan bagi kendaraan.

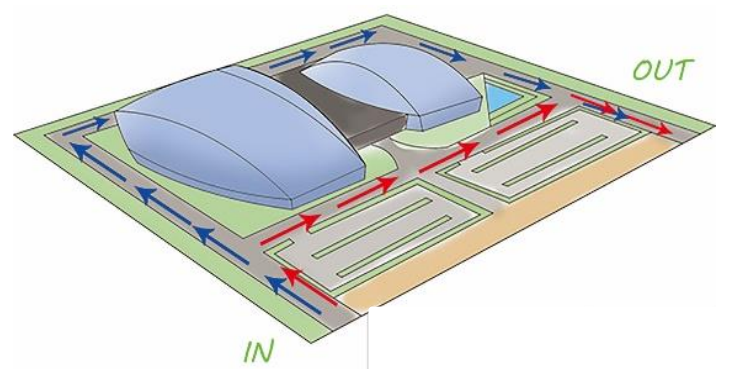

Gambar 21. Konsep Sirkulasi dan Parkir

Pada lingkupan lansekap diperlukan penataan vegetasi yang bagus dengan menggunakan beberapa pilihan tanaman existing yang berfungsi sebagai sun shading dan peneduh seperti penggunaan pohon ketapang dan pohon kiara payung. Beberapa tanaman juga diperlukan seperti pembatas, pengarah, dan sebagai buffer kebisingan disekitar site. Penataan vegetasi juga berfungsi sebagai 
estetika dari lingkupan lansekap dengan menggunakan pohon flamboyant dan pohon kamboja.

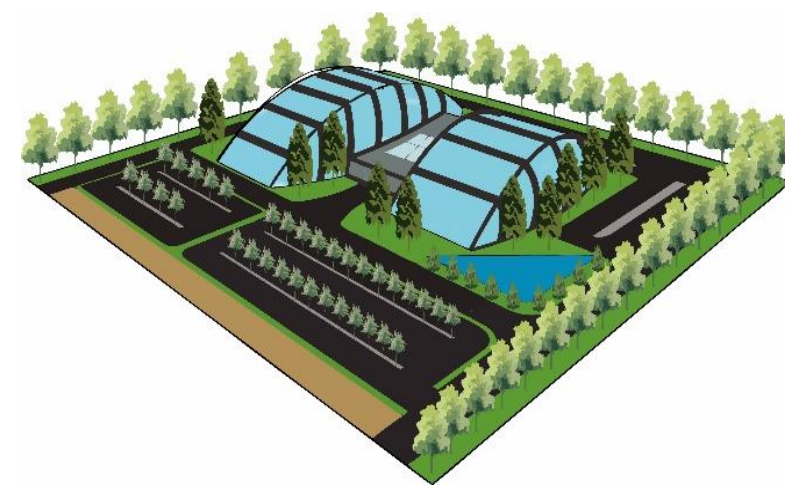

Gambar 22. Konsep Penataan Vegetasi

\subsection{Konsep Struktur}

Penerapan struktur yang diekspos identik pada gaya bangunan arsitektur high-tech yang mana struktur tidak hanya sebagai pemikul beban tetapi juga sebagai estetika dari bangunan itu sendiri. Penggunaan struktur rangka ruang pada bangunan Fitness and Wellness Center akan dieskpos dengan menerapkan bentuk pola kontraksi dan relaksasi otot.

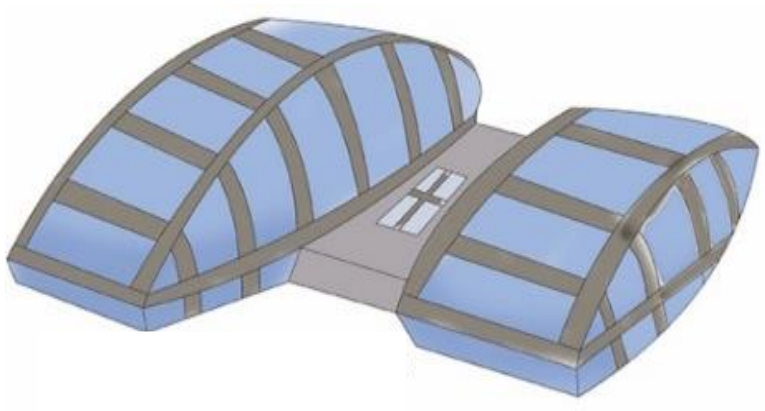

Gambar 23. Penerapan Konsep Pada Struktur

\section{KESIMPULAN}

Kesimpulan dari perancangan Fitness and Wellness Center di Pekanbaru dengan pendekatan Arsitektur High-Tech adalah sebagai Fitness and Wellness Center di Pekanbaru merupakan sebuah pusat kebugaran dan kesehatan jasmani dan rohani dengan menyediakan berbagai fasilitas-fasilitas yang mendukung kegiatan dari fitness dan wellness. Fasilitas utama pada perancangan ini terdiri dari fitness area, kardio, sauna, body contest sebagai wadah penyelenggaraan pertunukan maupun event perlombaan, yoga, senam aerobic, martial arts, renang dan lain sebagainya serta menyediakan fasilitas pendukung seperti cafeteria dan retail penjualan kebutuhan dalam berkegiatan kebugaran dan kesehatan jasmani dan rohani. Adapun prinsip-prinsip arsitektur high-tech yang akan diterapkan pada perancangan Fitness and Wellness Center adalah Struktur yang diekspose bukan hanya sebagai penahan beban namun juga sebagai estetika dari bangunan; Penggunaan material kaca dan baja sebagai material utama pada bangunan; Memperhatikan fleksibilitas ruang sehingga mampu menghasilkan ruang yang fleksibel; Teknologi, servis dan mekanikal menjadi pendukung fungsi dari bangunan; Transparansi bangunan sehingga bagian dalam bangunan diperlihatkan ke luar bangunan.

\section{REFERENSI}

Akbar, Rizky. 2008. Business Plan Rebel Gym Fitness Centre. Skripsi tidak diterbitkan. Universitas Islam Bandung. Bandung.

Endirastomo, Nurhadi. 2009. Pusat Animasi Di Yogyakarta Dengan Penekanan Arsitektur High Tech. Skripsi tidak diterbitkan. Universitas Sebelas Maret, Surakarta.

Gesyari, Intan Mentari Putri. 2018. Tirtomoyo Sport and Wellness Center Surakarta. Skripsi tidak diterbitkan. Universitas Muhammadiyah Surakarta, Surakarta.

Giriwijoyo, Santoso. (2007). Ilmu Faal Olahraga. Fakultas Pendidikan Olahraga dan Kesehatan Universitas Pendidikan Indonesia, Bandung.

Kusuma, Aji Bayu dan Tri Putra Wahyu (2017) Etno Wellness Sentuhan Ekonomis Air Terjun Sinduharjo (Berbasis Pemberdayaan Sosial). In: Kewirausahaan Dalam Multi Persfektif. Universitas Terbuka, Tangerang Selatan, pp. 73-82. ISBN 978-602-392-156-0

Neufert, Ernst. 1996. Data Arsitek: Jilid 1 Edisi 33. Erlangga, Jakarta.

Neufert, Ernst. 2002. Data Arsitek: Jilid 2 Edisi 33. Erlangga, Jakarta.

Nursamsiah, Endang Setyowati dan Karsih. 2015. Profil Social Self of Wellness Mahasiswa Strata 1 Fakultas Ilmu Pendidikan Universitas Negeri Jakarta. 
Jurnal Bimbingan Konseling, Vol.4, Issue. 2, Autumn: Hal 75.

Pratama, Rizki Aji. 2018 Solo Fitness Center (Pendekatan Konsep Green Architecture). Skripsi tidak diterbitkan. Universitas Muhammadiyah Surakarta, Surakarta.

Saputra, Adhitya Nuswantoro. 2019. Perancangan Interior Wellness Center Untuk Penderita Gangguan Psikis Ringan dan Relaksasi. Thesis tidak diterbitkan. Universitas Kristen Maranatha, Bandung. Syahira, Nurul. 2019. Prinsip Futuristik Pada Perancangan Fitness And Leisure. Skripsi tidak diterbitkan. Universitas Riau, Pekanbaru.

Telew, Meynar dan Steven Lintong. 2011. "Arsitektur High Tech". Media Matrasain, Vol.8, Issue.2, Autumn: Hal. 94-106. 